\title{
Vertical Changes of Holocene Ostracodes in Bore Hole Cores from off Kobe, Related to the Opening of Straits and Relative Sea-Level Change in Western Japan
}

\author{
Toshiaki Irizuki*1, Fujio Masuda*2, Basara Miyahara*2, Atsushi Hirotsu*3, \\ Shizuki Ueda* ${ }^{3}$ and Shusaku Yoshikawa*3
}

\begin{abstract}
Fossil ostracodes were studied in two bore hole cores (OB-1 and OB-2) from Osaka Bay off Kobe in western Japan to examine vertical changes in ostracode faunas. Fifty-two species were identified in 56 sediment samples. Based on numerical analyses of these ostracodes, the samples examined are grouped into five biofacies : BM (brackish mud), SM (shallow mud), SS (shallow sandy mud), DS (deep sandy mud) and DM (deep mud). These biofacies are distributed in upward sequence in both cores. From ca. 11,000-10,000 cal yrs BP, the predominant species living were those dominant in enclosed inner brackish bays at water depths of $2-7 \mathrm{~m}$. Inner to middle, enclosed shallow muddy bay species increased at the study sites after the opening of the Akashi Strait (ca. 9,700 cal yrs BP). Ostracode assemblages changed ca. 8,000 cal yrs BP, when Osaka and Harima-nada Bàys were connected with Mizushima-nada Bay. Tidal currents from the Akashi Strait have since been strong. As a result, specimens of intertidal to shoreface species were transported with sandy sediments into deeper Osaka Bay off Kobe. Thus, their individual numbers increased rapidly. A peak in the number of intertidal to shoreface species and deep mud-dwellers occurred around 5,500 cal yrs BP, suggesting that tidal currents from the Akashi Strait and paleo-water depth reached their maxima at this time (ca. $33 \mathrm{~m}$ ). These species then decreased with time, with the start of a regression. After ca. 2,000-1,600 cal yrs BP, mud-dwellers inhabiting enclosed, organic matter-rich bays were abundant. Their numbers increased further as coarse materials from the Akashi Strait decreased and the Yodo River began to bring flood clays into the study sites. Both "form A" and "form M" of Bicornucythere bisanensis are present in both core samples. "Form M" first invaded the study sites through the Kitan Strait to the south. "Form A" came to Osaka Bay off Kobe, ca. 8,350-8,000 cal yrs BP, and has since become the dominant of the two forms.
\end{abstract}

Key Words : Ostracoda, Osaka Bay, Holocene, Akashi Strait, sea-level change

\section{Introduction}

Eustatic rise in sea level occurred after the last glacial maximum at about 20,000 years ago. Sea level reached its maximum height (higher than it is at present) in Japan ca. 6,500 $-5,000$ years before present, as estimated by carbon isotope dating $\left({ }^{14} \mathrm{C}\right.$ yrs BP) (Ota et al., 1990). This transgression is called the Jomon transgression. During this period, seawater

Received May 29, 2000. Accepted October 28, 2000.

*1 Department of Earth Sciences, Aichi University of Education. 1 Hirosawa, Igaya-cho, Kariya, 448-8542, Japan. E-mail

*2 Department of Geology and Mineralogy, Graduate School of Science, Kyoto University. Kitashirakawa oiwake-cho, Sakyo-ku, Kyoto, 606-8502, Japan.

*3 Department of Geosciences, Faculty of Science, Osaka City University. 3-3-138 Sugimoto, Sumiyoshi-ku, Osaka, 558-8585, Japan. 
inundated basins that were formed by erosion during the last glacial period. Drowned valleys and small enclosed bays developed inland. Many straits opened around the Japanese islands (Ota et al., 1990).

Many authors have reported the developmental history of the Osaka Plain and its adjacent areas during the Holocene period (e.g., Kajiyama and Itihara, 1972 ; Maeda, 1976, 1978). Maeda $(1976,1978)$ surmised that the maximum height of sea level was about $3 \mathrm{~m}$ above present level. Kawachi Bay formed to the east of Osaka Bay at the height of the Jomon transgression (Kajiyama and Itihara, 1972). Recently, Miyahara et al. (1999) studied sedimentary facies and fossil ostracode faunas. They also conducted high density radiocarbon dating of molluscan shells, downcore in a single bore hole core at Kitatsumori in the Osaka Plain. Masuda et al. (2000) suggested that a peak in sea level occurred in Osaka Bay at ca. 5,300$5,000 \mathrm{cal}$ yrs BP. Onodera and Oshima (1983) described the geomorphological history of the eastern Seto Inland Sea through analyses of continuous seismic reflection records, bottom core samples, radiocarbon dates and surface topography. Masuda et al. (2000) studied sedimentary facies and performed stratigraphical, high density radiocarbon dating at the same bore holes as those examined in the present study in Osaka Bay off Kobe.

Holocene marine events have strongly influenced the composition and structure of shallow marine invertebrate assemblages, including those of molluscs, foraminifers and ostracodes. Ostracoda, which is the subject of this study, is small and bivalved Crustacea. Some authors have investigated temporal changes of Holocene ostracode assemblages in Japan (Frydl, 1982 ; Ota et al., 1985 ; Ikeya et al., 1990 ; Iwasaki, 1992 ; Kamiya and Nakagawa, 1993 ; Irizuki et al., 1998, 1999 ; Miyahara et al., 1999 ; Yasuhara et al., 1999b). Many of these studies involve ostracode assemblages in small drowned valleys, facing open coastal seas during the Jomon transgression. Similar vertical changes of ostracode assemblages are reported. Miyahara et al. (1999) and Yasuhara et al. (1999b) studied Holocene ostracodes from bore hole cores in the Osaka Plain. On the other hand, we have examined bore hole cores drilled from the surface of the seabed off Kobe. These regions have been influenced by tidal currents from the west and fresh water from rivers to the east. Therefore, temporal sequences of ostracodes in Osaka Bay off Kobe are assumed to be different from those in the Osaka Plain and from other small drowned valleys.

The aim of this study is to elucidate the intricate relationships among temporal sequences of ostracodes, the opening of straits and the relative sea-level changes during the Holocene period in Osaka Bay off Kobe.

\section{Materials and methods}

Osaka Bay is a large enclosed bay in western Japan, connected with the Pacific Ocean (Kii Channel) through the Kitan Strait to the south, and with Harima-nada Bay through the Akashi Strait to the west (Fig. 1). Harima-nada Bay is linked with the western Seto Inland Sea (Mizushima-nada and Hiuchi-nada Bays) through the Bisan-Seto Strait to the west, and with the Pacific Ocean (Kii Channel) through the Naruto Strait to the south. The bottom of

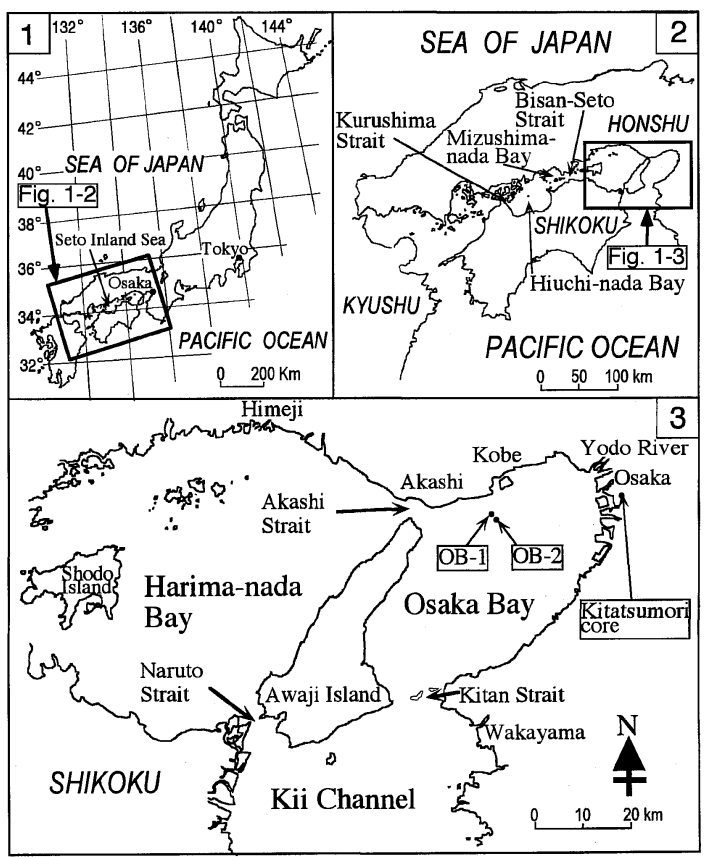

Fig. 1 Index and locality maps 
eastern Osaka Bay slopes gently westward, beneath water extending to depths of $10-20 \mathrm{~m}$. It is covered with flood clay derived from the Yodo River and other small rivers at the eastern margin (Fig. 1-3). In the western half of the bay, sand to sandy mud is transported from the Akashi Strait at the western margin and from the Kitan Strait lying to the south. Some cardons have developed around those straits (e.g., Onodera and Oshima, 1983), where deposits range from sand to sandy gravel. We used two bore hole cores (OB-1 and OB-2) drilled by Japan Coast Guard in the western part of Osaka Bay (Fig. 1-3). Masuda et al. (2000) reported briefly on the ostracodes from the $\mathrm{OB}^{-1}$ core. This core is situated at a water depth of $21.72 \mathrm{~m}, 4 \mathrm{~km}$ off Kobe $\left(34^{\circ} 36^{\prime} 18.3^{\prime \prime} \mathrm{N}, 135^{\circ} 9^{\prime}\right.$ $\left.20.7^{\prime \prime} \mathrm{E}\right)$. The $\mathrm{OB}-2$ core is situated at a water depth of $21.91 \mathrm{~m}, 5 \mathrm{~km}$ off Kobe $\left(34^{\circ} 35^{\prime} 48^{\prime \prime} \mathrm{N}\right.$, $\left.135^{\circ} 9^{\prime} 29.1^{\prime \prime} \mathrm{E}\right)$. Bottom surfaces at both sites are covered mainly with mud, derived from the Yodo and other rivers, flowing through eastern regions of Osaka Bay. We collected 36 samples from the marine sediments above 29.5 -m core depth in $\mathrm{OB}-1$ and 32 samples from the marine sediments above $32.17-\mathrm{m}$ core depth in OB-2 (Fig. 2). An interval between samples is typically one meter, though sample spacing is reduced for selected horizons.

We initially measured the water content of all samples. We then collected $30 \mathrm{~g}$ of wet sediments and washed them with water on three piled mesh sieve screens (opening is 25 $\mu \mathrm{m}$ (500 mesh), $63 \mu \mathrm{m}$ (250 mesh) and $250 \mu \mathrm{m}$ (60 mesh)). We divided samples containing excessive ostracodes into workable aliquots using a sample splitter. After that, we picked about 200 specimens on each assemblage slide from samples coarser than $250 \mu \mathrm{m}$. The number of specimens refers to the sum of either right or left valves of each species.

\section{Sedimentary facies and ages of study cores}

Masuda et al. (2000) described in detail the Holocene marine sediments above the transgressive surface (29.5-m core depth) within the OB- 1 core and divided them into four sedimentary facies (Fig. 2). We briefly mention those facies here and correlate them to those of the

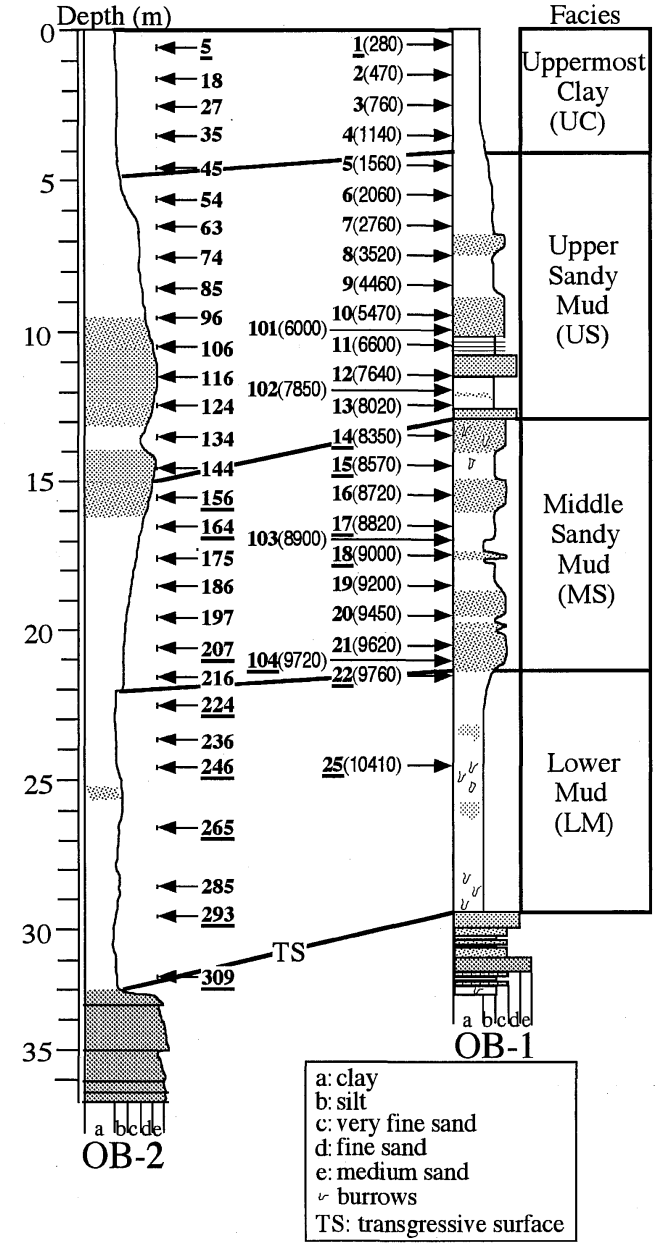

Fig. 2 Columnar sections of $\mathrm{OB}^{-1}$ and $\mathrm{OB}^{-}-2$ cores and horizons of ostracode bearing samples Numerals with underline show samples less than 50 individuals. Numerals in parentheses mean radiocarbon age (calendar yrs BP) of each sample of OB-1 core as estimated from depositional curve of Masuda et al. (2000). Sedimentary facies of OB-1 core are based on Masuda et al. (2000).

OB-2 core as follows :

\section{Lower Mud (LM)}

Lower Mud at depths of $29.5-21.0 \mathrm{~m}$ in $\mathrm{OB}^{-}$ 1 and $32.17-22.0 \mathrm{~m}$ in $\mathrm{OB}-2$ consists mainly of clean clay, partly intercalating silt layers. Bioturbation and shells are common. The lowermost part of LM is composed of organic matter-rich, sandy silt. Brackish molluscs (Potamocorbula amurensis) and diatoms (Hydo- 
rosera triquetra) occur at depths of $26.0-24.4 \mathrm{~m}$ and ca. $28.5 \mathrm{~m}$ in $\mathrm{OB}-1$, respectively.

\section{Middle Sandy Mud (MS)}

Middle Sandy Mud at depths of $21.0-13.0 \mathrm{~m}$ in $\mathrm{OB}^{-1}$ and $22.0-15.0 \mathrm{~m}$ in $\mathrm{OB}-2$ consists mainly of massive well-sorted, very fine sand and intercalating silt layers. Intensive bioturbation is apparent, especially in the uppermost part. Mud content decreases upward.

\section{Upper Sandy Mud (US)}

Upper Sandy Mud is distributed at depths of $13.0-4.0 \mathrm{~m}$ in $\mathrm{OB}^{-}-1$ and $15.0-5.0 \mathrm{~m}$ in $\mathrm{OB}-2$. The lower part of US is composed of silt and intercalating graded bedding intervals of fine to very fine sand, whereas the upper part (at depths of $7.0-4.0 \mathrm{~m}$ in $\mathrm{OB}-1$ ) is entirely silt. Volcanic glasses are concentrated at depths of $11.5-10.5 \mathrm{~m}$ in OB-1. Masuda et al. (2000) suggest that these volcanic glasses correlate with the Kikai-Akahoya volcanic ash (K-Ah), dated at 7,300 cal yrs BP (Fukusawa, 1995). Some molluscan species that characteristically inhabit water depths from ca. 20-250 m (including Zeuxis siquijorensis, Microcirce dilecta, and Myadora fluctuosa) are found at depths of 12.0 $-6.5 \mathrm{~m}$ in $\mathrm{OB}-1$.

\section{Uppermost Clay (UC)}

Uppermost Clay at depths of $4.0-0 \mathrm{~m}$ in $\mathrm{OB}$ -1 and $5.0-0 \mathrm{~m}$ in $\mathrm{OB}^{-2}$ is composed of clean clay with bioturbation. Shallow-water molluscan shells (such as Theol fragilis, Solen strictus and Veremorpa micra) are recognizable in OB-1.

The lower (LM) and upper (UC) strata are mainly comprised of clay, derived from the Yodo and other rivers flowing through the eastern regions of Osaka Bay. On the other hand, the middle (MS and US) strata are com- posed of relatively coarse-grained sediments (well-sorted coarse silt to fine sand), discharged from the Akashi Strait to the west.

Using the AMS method, Masuda et al. (2000) conducted radiocarbon dating of molluscan shell fragments, collected at 32 horizons of the marine section in the OB- 1 core. From these data, they constructed a depositional curve for OB-1. Their results indicate that depositional rates are high in LM (ca. $8 \mathrm{~mm} / \mathrm{yr}$ ), MS (ca. 7 $\mathrm{mm} / \mathrm{yr})$ and UC $(4 \mathrm{~mm} / \mathrm{yr})$ facies and low in the US facies $(0.9-1.8 \mathrm{~mm} / \mathrm{yr})$. Ages in calendar years before present are given for all ostracodebearing samples from $\mathrm{OB}^{-1}$ (Fig. 2), as calculated on the basis of the depositional curve constructed by Masuda et al. (2000). We have no data on radiocarbon dating in the $\mathrm{OB}-2$ core.

\section{Biofacies based on ostracode assemblages}

We identified 52 ostracode species in 56 samples (27 samples in $\mathrm{OB}^{-1}$ and 29 samples in OB-2 ; Table 1). Figure 3 shows scanning electron micrographs of selected ostracodes. All ostracodes are commonly found around Japan today except Neomonoceratina delicata, which has never been reported from contemporary Japanese bays. We carried out a conventional multivariate analysis (Q-mode cluster analysis) to group samples quantitatively. We adopted the group average method based on the overlap index of Horn (1966) (Fig. 4). We used 31 species, each represented by more than three specimens, in any of the 39 samples containing more than 50 specimens. By this means, five clusters were distinguished (Fig. 4). These clusters are referred to as biofacies. Biofacies

Fig. 3 Scanning electron micrographs of fossil ostracodes from boring core in Osaka Bay off Kobe Scale bars $=0.5 \mathrm{~mm}$ (A for $1-4,15-17$; b for $5-14,18$ ). All specimens are right valves. 1 . Krithe japonica Ishizaki (sample no. 1-5), 2. Spinileberis quadriaculeata (Brady) (sample no. 2-197), 3. Cythere nishinipponica Okubo (sample no. 2-144), 4. Schizocythere asagao Yajima (sample no. 2-96), 5. Aurila spinifera s.l. Schornikov and Tsareva (fine reticulation form) (sample no. 1-12), 6. Aurila spinifera s.l. Schornikov and Tsareva (coarse reticulation form) (sample no. 1-101), 7. Trachyleberis scabrocuneata (Brady) (sample no. 2-144), 8. Trachyleberis sp. (sample no. 2-144), 9. Amphileberis nipponica (Yajima) (sample no. 1-6), 10. Bicornucythere bisanensis (Okubo) (Form A, adult female) (sample no. 1-12), 11. Bicornucythere bisanensis (Okubo) (Form A, A-1 instar) (sample no. 1-12), 12. Pistocythereis bradyi (Ishizaki) (sample no. 2-197), 13. Bicornucythere bisanensis (Okubo) (Form M, adult female) (sample no. 1103), 14. Bicornucythere bisanensis (Okubo) (Form M, A-1 instar) (sample no. 1-103), 15. Cytheropteron uchioi Hanai (sample no. 2-106), 16. Loxoconcha viva Ishizaki (sample no. 1-7), 17. Cytheromorpha acupunctata (Brady) (sample no. 1-10), 18. Kobayshiina donghaiensis Zhao (sample no. 1-8) 
BM is situated in the lower part of the $\mathrm{OB}-2$ core (sedimentary facies LM). The other four biofacies, SM, SS, DS and DM, are located in upper sections in both cores. Figures 5 and 6 show vertical changes in the percentage of selected ostracodes, numbers of species and biofacies of $\mathrm{OB}^{-1}$ and $\mathrm{OB}^{-2}$, respectively.
Figure 7 illustrates temporal changes in the numbers of individual ostracodes per 10 -g sediment sample (referred to herein as "ostracode number") at OB-1, for the selected species and biofacies.

\section{Biofacies BM (brackish mud)}

Biofacies BM comprises only one sample
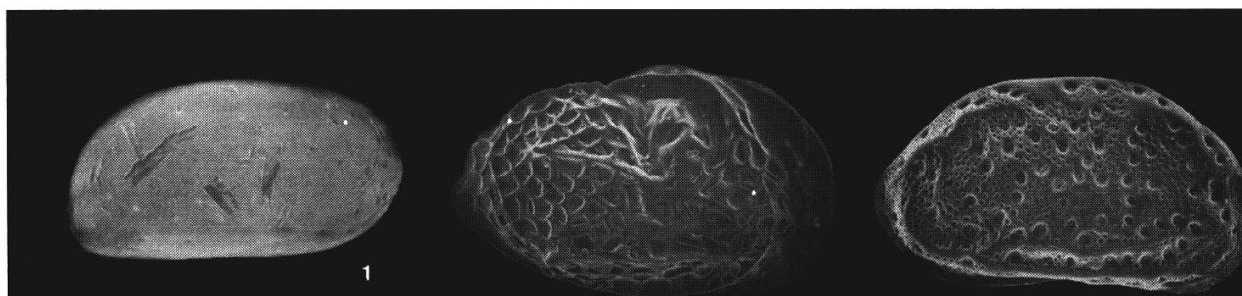

2
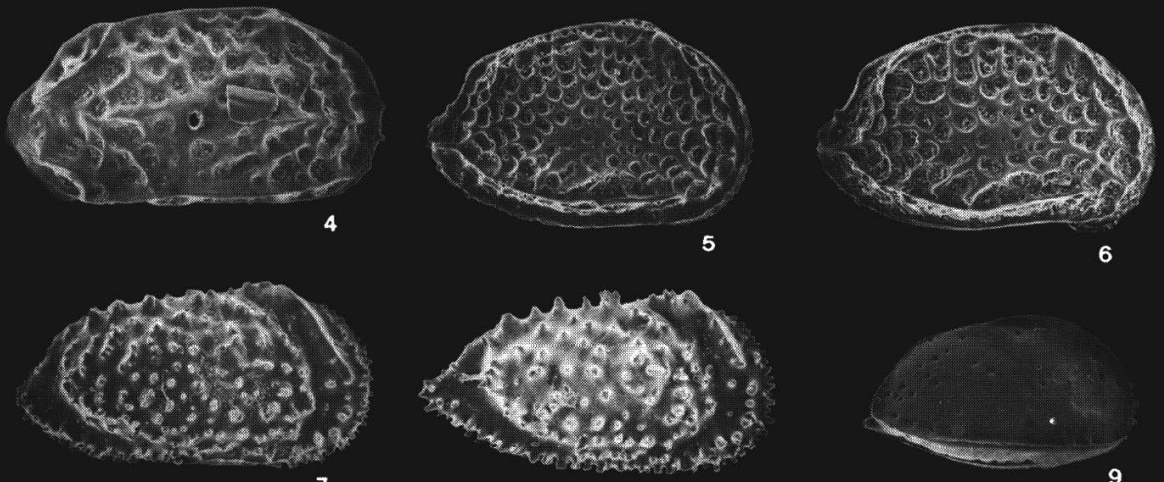

6

8
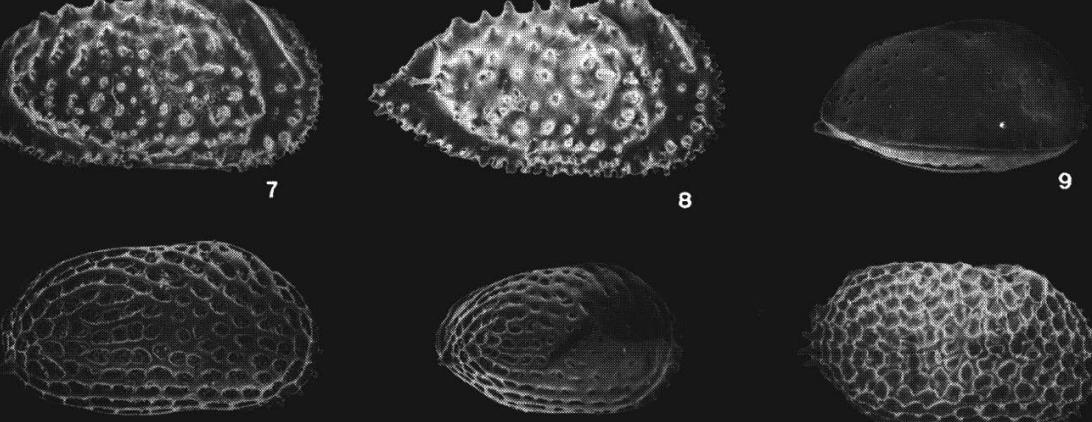

10
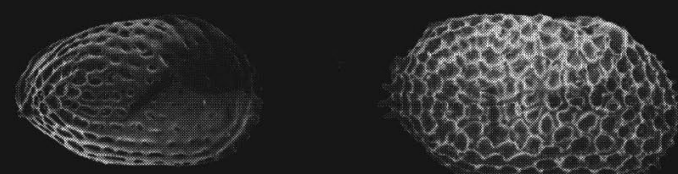

11

12

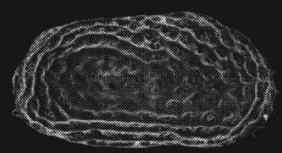

13

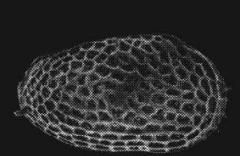

14

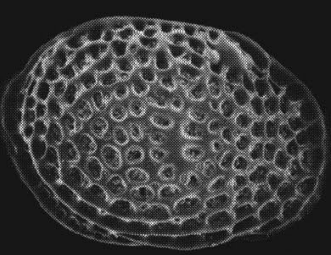

16
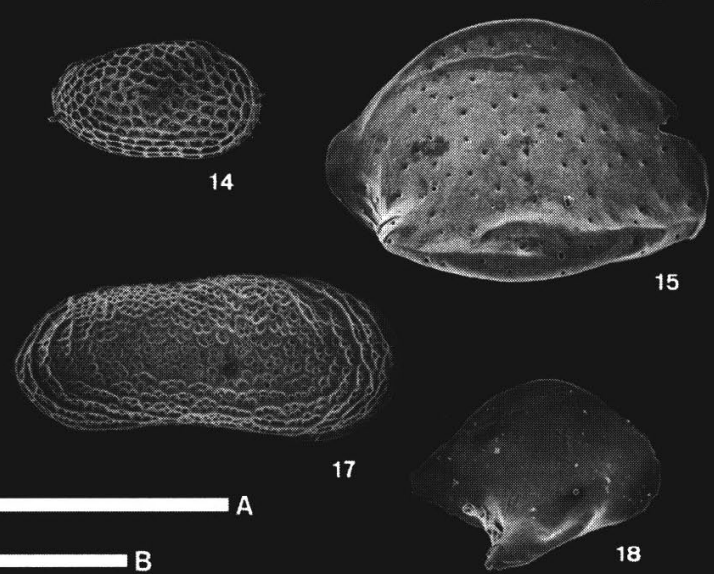

15

17

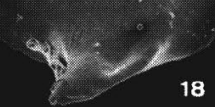


Table 1 List of ostracodes from OB-1 and OB-2 cores

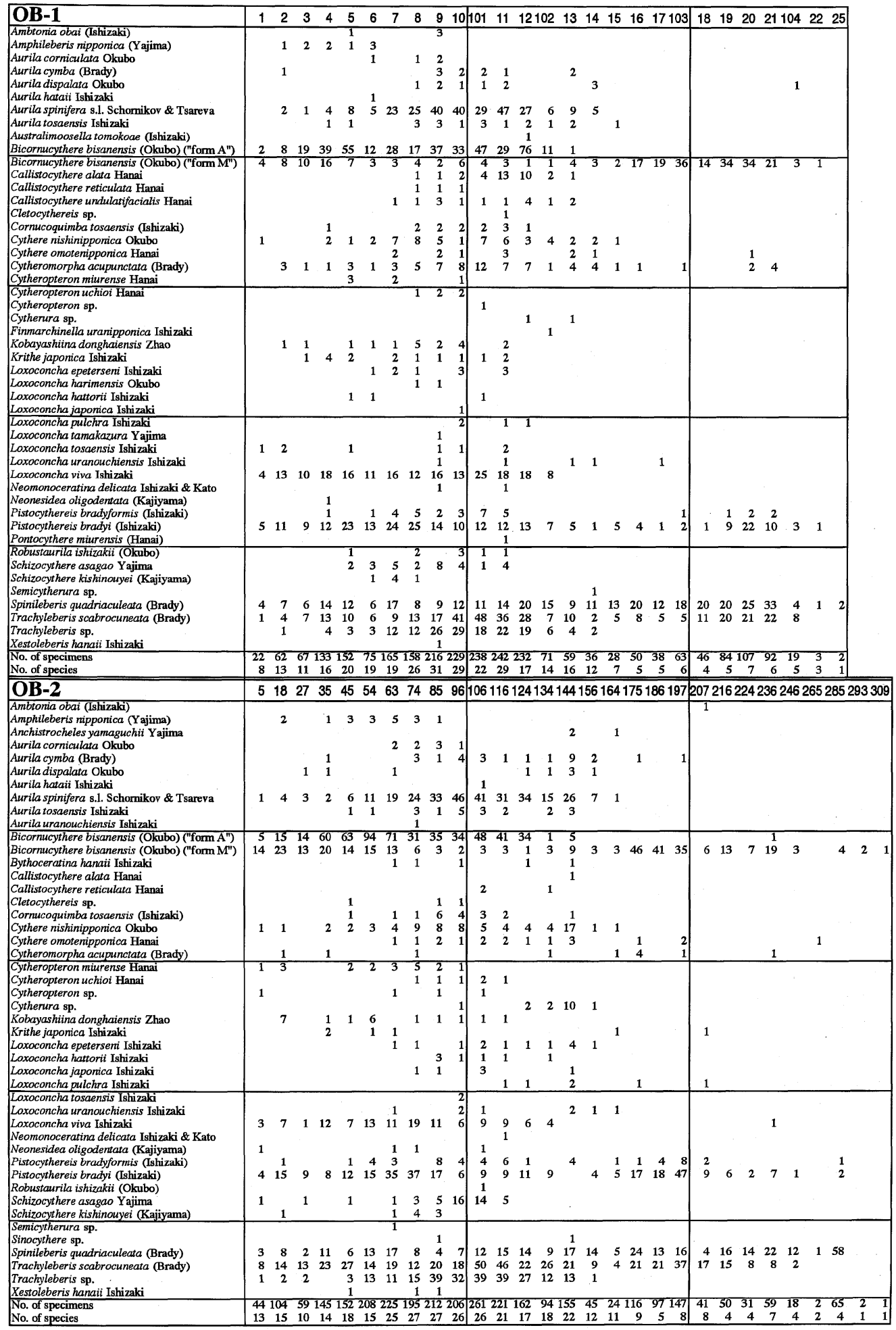




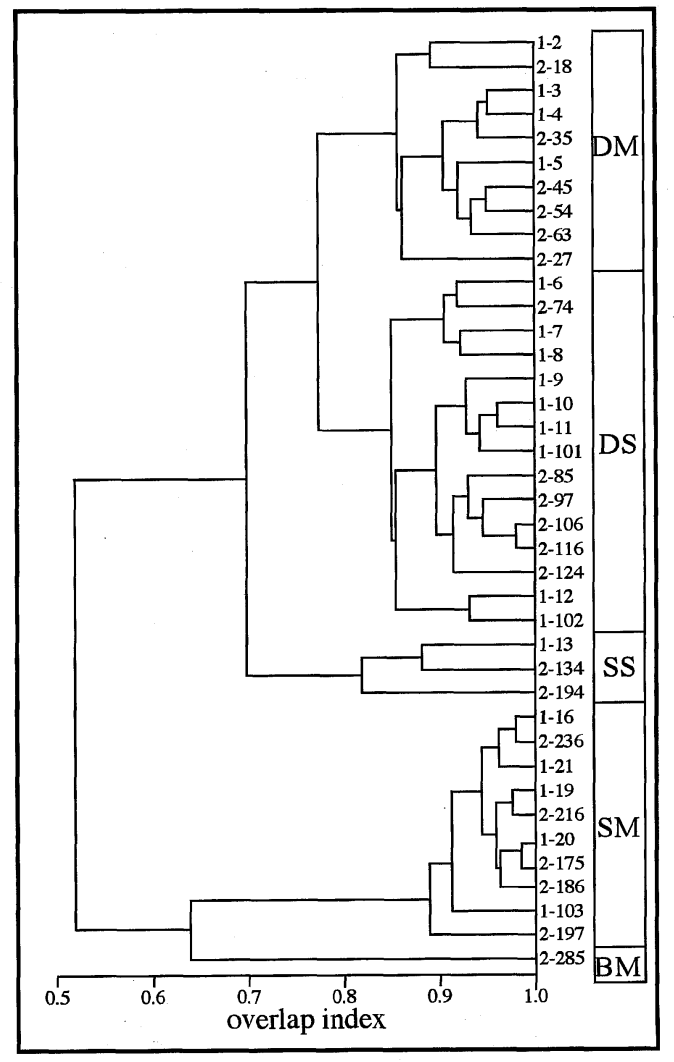

Fig. 4 Dendrogram of Q-mode cluster analysis BM, SM, SS, DS and DM refer to biofacies.

(number 285) from the middle part of LM in OB -2 . It is characterized by an overwhelming preponderance (about 89\%) of the species Spinileberis quadriaculeata. Of the four constituent species, the other three are "form M" of Bicornucythere bisanensis (Abe and Choe, 1988), Pistocythereis bradyformis and P. bradyi.

Spinileberis quadriaculeata has been reported as a dominant species at water depths of 2-14 $\mathrm{m}$. it is, however, more abundant on muddy substrates $(\mathrm{Md}=5$ to $8 \phi)$ in inner brackish bays (where salinity reaches $20-30 \%$ ) at water depths of $2-7 \mathrm{~m}$ (Ikeya and Shiozaki, 1993). It is not a dominant species in these environments in contemporary Osaka Bay, which is deeper than $8.8 \mathrm{~m}$ (Yasuhara et al., 1999a). Bicornucythere bisanensis has been reported to be common at water depths ranging from 2 $-16 \mathrm{~m}$. It is more abundant on muddy substrates $(\mathrm{Md}=5$ to $7 \phi)$ in inner to middle brack- ish bays (where salinity is $20-30 \%$ ) at depths of $5-9 \mathrm{~m}$ (Ikeya and Shiozaki, 1993). This biofacies is interpreted as a deposit formed in an inner brackish muddy bay, shallower than about $10 \mathrm{~m}$ during an early transgression.

\section{Biofacies SM (shallow mud)}

Biofacies SM is composed of 11 samples. It lies in the MS facies of $\mathrm{OB}^{-} 1$, and in the interval between the upper part of LM and the middle to upper part of MS in OB-2. This biofacies is characterized by the dominance of "form M" of B. bisanensis, S. quadriaculeata, P. bradyi and Trachyleberis scabrocuneata. The relative abundance of S. quadriaculeata is $23-40 \%$ in OB-1 and $11-37 \%$ in $\mathrm{OB}^{-2}$. It decreases upward in OB-2. The number of species is small : four to nine.

Trachyleberis scabrocuneata and $P$. bradyi are commonly found in the shallow muds of enclosed bays (e.g., Ishizaki, 1968 ; Yasuhara et al., 1999a). The decrease in relative abundance of $S$. quadriaculeata and the increase in abundance of $B$. bisanensis possibly indicate an increase in water depth. This biofacies is interpreted as a deposit in an inner to middle, enclosed shallow muddy bay deeper than biofacies BM.

\section{Biofacies SS (shallow sandy mud)}

Biofacies SS is composed of three samples (number 13 in $\mathrm{OB}^{-1}$, and numbers 134 and 144 in $\mathrm{OB}-2)$. This biofacies is present in the lowermost part of the US facies in both cores. Biofacies SS is characterized by the occurrence of Aurila spinifera s.l. and Trachyleberis sp., both of which are never found in underlying biofacies DM and SM. Spinileberis quadriaculeata and T. scabrocuneata are also common in this biofacies. There is a moderate number of species in SS : 16 to 22 .

Aurila spinifera s.l. in this study corresponds to both forms of Aurila cymba (fine reticulate form) described by Yamane (1998) and to Aurila cf. kiritsubo (coarse reticulate form). The latter conforms to A. spinifera described by Schornikov and Tsareva (1995). The adult specimens in the present study show the gradation from fine to coarse reticulation. Thus, we tentatively assign them to A. spinifera s.l. Aurila spinifera s.l. is reported from sand to sandy bottoms in Hiuchi-nada Bay near the 


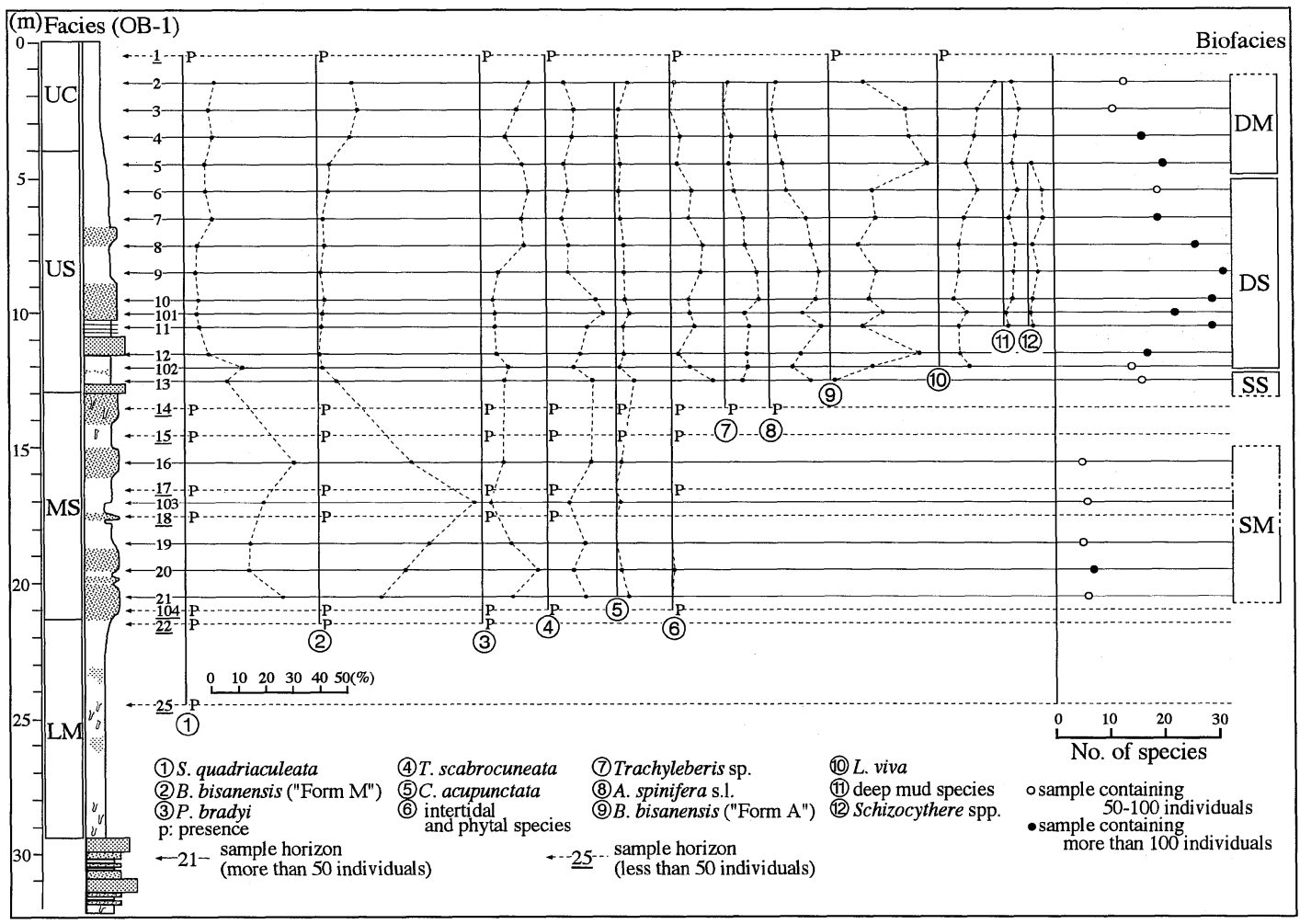

Fig. 5 Columnar section of $\mathrm{OB}^{-1}$ core, sample horizons, percentages of dominant species, number of species and biofacies

Deep mud species are Ambtonia obai, Amphileberis nipponica, Cytheropteron uchioi, Kobayashiina donghaiensis and Krithe japonica. Intertidal and phytal species are Aurila spp. except for A. spinifera s.1., Cornucoquimba tosaensis, Cythere spp., Loxoconcha spp. except for L. pulchra, L. tosaensis and L. viva, Neonesidea oligodentata, Robustaurila ishizakii and Xestoleberis hanaii.

Kurushima Strait (Yamane, 1998) and in Osaka Bay, where the influence of tidal currents from the Akashi Strait is felt (Yasuhara et al., 1999a). Moreover, "form A" of B. bisanensis (Abe and Choe, 1988) occurs in this biofacies in OB-1. It is represented only by a single juvenile valve in underlying biofacies SM (sample number 236) in OB-2. Trachyleberis sp., often confused with $T$. scabrocuneata, is also a characteristic species in Osaka Bay near the Akashi Strait (Yasuhara et al., 1999a). This biofacies is interpreted as a deposit formed in a sandy shallow bay under the mild influence of tidal currents.

\section{Biofacies DS (deep sandy mud)}

Biofacies DS consists of 15 samples and covers almost the whole interval of US facies. It is characterized by a high relative abundance of A. spinifera s.l., "form A" of B. bisanen- sis and Trachyleberis sp. Cythere and Schizocythere species are also common in this biofacies. The ostracode number is high, especially for A. spinifera s.l. and Trachyleberis spp. The number of species reaches its maximum in this biofacies : $14-31$ in OB-1 and $17-27$ in OB-2. Cytheropteron uchioi is present in the middle part of this biofacies (sample numbers $8-10$ in OB-1 ; sample numbers $74-116$ in OB-2) (Table $1)$.

The ostracode number of such sand-dwellers as A. spinifera s.1., Trachyleberis sp. and "form $\mathrm{A}$ " of $B$. bisanensis increases in this biofacies. Cythere and Schizocythere are reported from Zostera beds in the intertidal zones and on the open sandy shorefaces, respectively (Hanai et al., 1977). Cytheropteron uchioi is reported at water depths of more than $20 \mathrm{~m}$ around central 


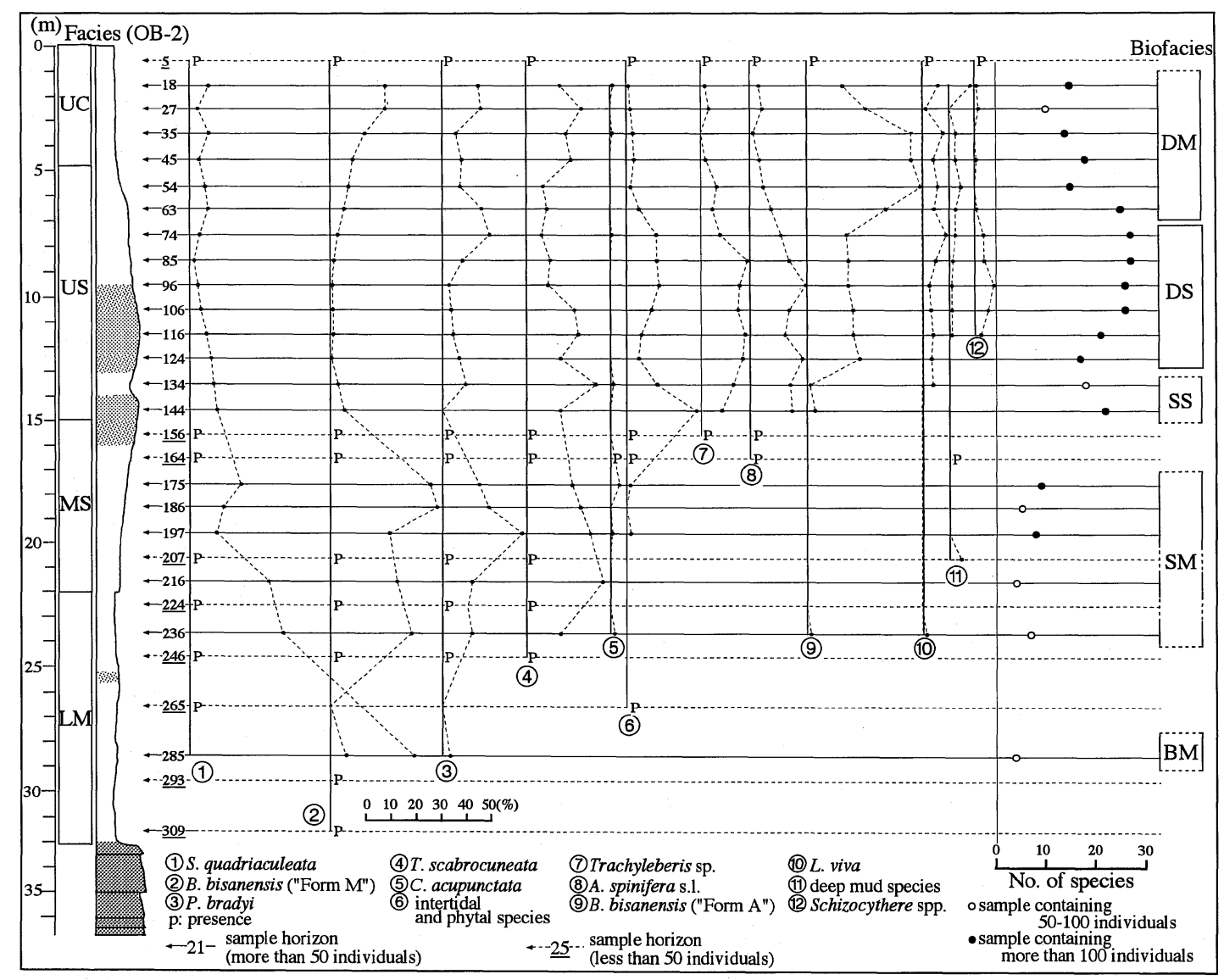

Fig. 6 Columnar section of $\mathrm{OB}-2$ core, sample horizons, percentages of dominant species, number of species and biofacies

For intertidal and phytal species and deep mud species, see Figure 5.

to southwestern Japan and China (e.g., Frydl, 1982 ; Zhao and Wang, 1988; Iwasaki, 1992; Yamane, 1998), but is recognized commonly at water depths exceeding $30 \mathrm{~m}$ (Zhao and Wang, 1988). Thus, phytal species, sand- and muddwellers, or deep and shallow species mix in this biofacies. Yamane (1998) investigated the distribution patterns of recent ostracodes from Hiuchi-nada Bay, southern Japan (Fig. 1-2). The ostracode "association A" of Yamane (1998) is similar to biofacies DS of the present study. It is distributed in silty sand to sand at about 16 $-33 \mathrm{~m}$ in water depth near the Kurushima Strait in the western part of Hiuchi-nada Bay (Fig. 1-2). "Association A" is composed mainly of dead specimens of sandy and phytal species. The specimens are thought to have been trans- ported from intertidal and sandy shorefaces around the Kurushima Strait by tidal currents and to have accumulated in deeper regions (Yamane, 1998). Therefore, it is possible that phytal species and sand-dwellers in biofacies DS were transported with sand from intertidal zones and shorefaces around the Akashi Strait, to the seabed at water depths of $20-30 \mathrm{~m}$ or more, by strong tidal currents.

\section{Biofacies DM (deep mud)}

Biofacies DM is composed of 10 samples and is present in the uppermost part of the US and $\mathrm{UC}$ facies. It is characterized by the dominance of "form A" and "form M" of B. bisanensis, $P$. bradyi, and Loxoconcha viva. Amphileberis nipponica, Kobayashiina donghaiensis and Krithe japonica also occur in some samples. 


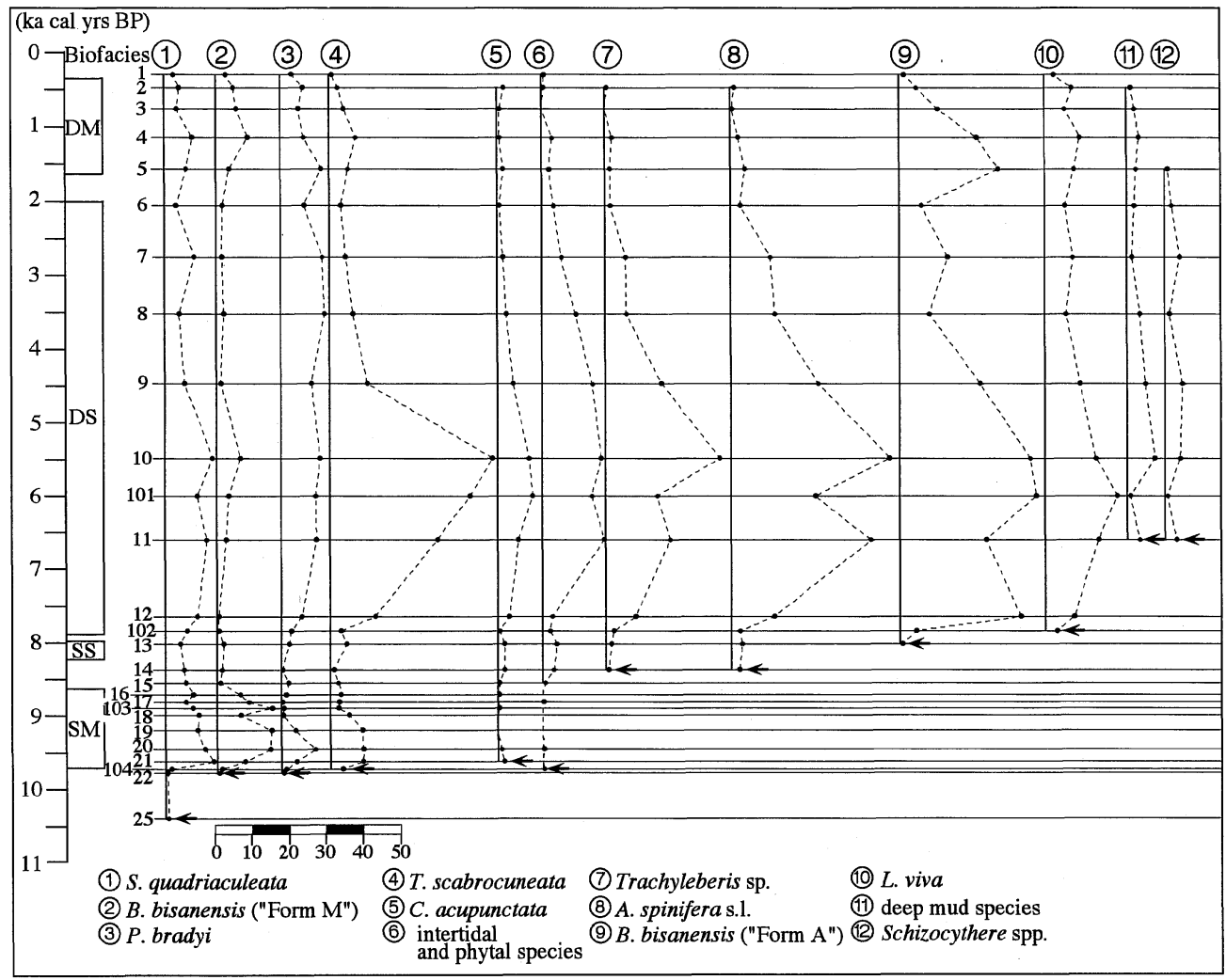

Fig. 7 Temporal changes of biofacies and individual number per 10-g sediment sample for each species in $\mathrm{OB}^{-1}$ core

A horizontal scale shows the number of individuals. Arrows show the first occurrences.

Minor constituents of this biofacies include $A$. spinifera s.l., Trachyleberis sp. and phytal species, all of which are characteristic of the underlying biofacies SS and DS. There is a moderate number of species : $11-20$ in $\mathrm{OB}^{-1}$, and 14 -18 in $\mathrm{OB}-2$.

All dominant species in biofacies DM have been reported from muddy bottoms. Amphileberis nipponica, Ko. donghaiensis and $K$. japonica are common at water depths of more than 15-20 m around Japan (e.g., Frydl, 1982 ; Bodergat and Ikeya, 1988; Iwasaki, 1992 ; Yamane, 1998). Yasuhara et al. (1999a) reported these ostracodes as characteristic species of muddy bottoms at water depths of $17.2-37.2$ $\mathrm{m}$ in middle Osaka Bay. Then, this biofacies is interpreted as a deposit formed in an enclosed, middle muddy bay at water depths of more than $15-20 \mathrm{~m}$.

\section{Relationships among temporal changes of ostracodes, the opening of straits and relative sea-level changes}

Onodera and Oshima (1983) constructed structure contour maps to show the boundary between Holocene marine sediments and underlying deposits in Harima-nada Bay, Kii Channel and Osaka Bay (Fig. 1-3). They inferred that the Kitan, Naruto and Akashi Straits had opened when sea level reached about $-60 \pm 5 \mathrm{~m},-50 \mathrm{~m}$, and $-35 \mathrm{~m}$, respectively. Masuda et al. (2000) dated the base of the LM facies (i.e., the transgressive surface) of $\mathrm{OB}$ -1 at ca. 11,000 cal yrs BP (event (1) in Fig. 8) and placed it about $51.0 \mathrm{~m}$ below the present sea level. At this horizon, seawater reached to the study area $(\mathrm{OB}-1)$. Ostracodes appear in the 


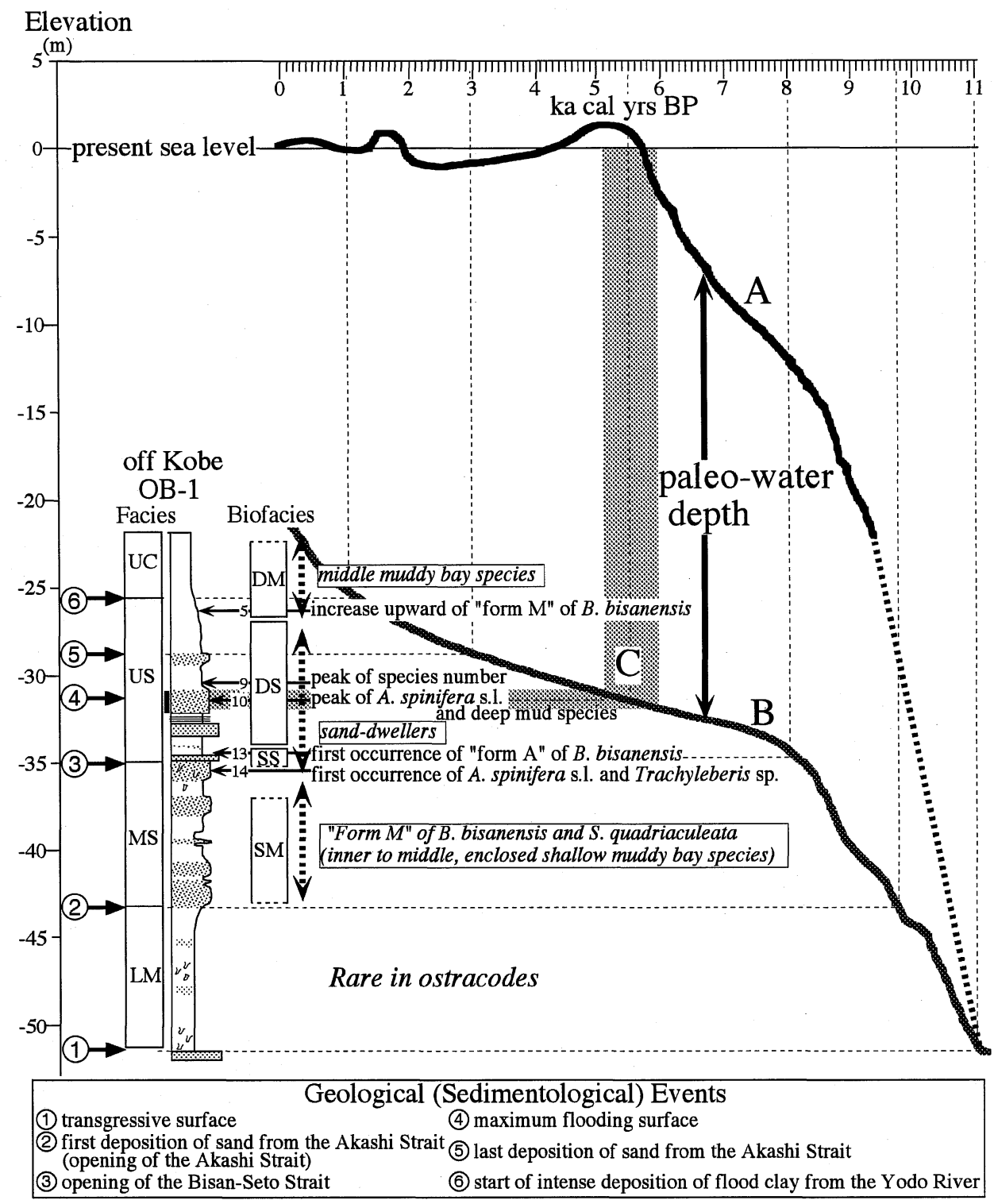

Fig. 8 Summary of geological (sedimentological) and ostracode events detected in OB-1 core off Kobe Relative sea-level curve (A) and depositional curve (B) are after by Masuda et al. (2000). $\mathrm{C}$ means the maximum flooding surface.

lowermost part of the LM facies in OB-2 (sample number 309). The LM facies is flood clay derived from rivers and accumulated in study sites during an early transgression (ca. $11,000-9,700 \mathrm{cal}$ yrs BP in OB-1). One sample taken from the LM facies belongs to biofacies $\mathrm{BM}$, characterized by inner brackish muddy. bay species (Fig. 6).
Based on the analysis of sedimentary facies and the seismic profile in Osaka Bay, Masuda et $a l$. (2000) suggested that the MS facies is a tidal delta deposit. Moreover, they indicated that the base of MS represents the advent of tidal currents passing through the Akashi Strait at OB-1 (ca. 9, 700 cal yrs BP) (event (2) in Fig. 8). Coarser grained silt then flowed from the west 
into the study sites in Osaka Bay, with the opening of the Akashi Strait. The ostracode number of inner to middle, enclosed shallow muddy bay species, characterizing biofacies $\mathrm{SM}$, increased around the boundary between the LM and MS facies in OB-1 (Fig. 6). On the other hand, the base of biofacies SM in $\mathrm{OB}^{-} 2$ is situated in the upper part of the LM facies (Fig. 6). Thus, the first deposition of coarser grained silt transported from the Akashi Strait at OB-2 is thought to have been later than that at $\mathrm{OB}^{-}$ 1. This may be ascribed in part to the farther position of OB-2 from the Akashi Strait.

There are slight changes to the ostracode faunas at the horizon uppermost in the MS facies, which may correspond to the lower part of biofacies SS. Aurila spinifera s.l. and Trachyleberis sp., characterizing biofacies SS and DS, first occur in sample number 14 in OB -1 (Fig. 5 and Table 1). They increase with height in the section (Figs. 5 and 8). "Form A" of $B$. bisanensis and Callistocythere spp. first occur in sample number 13 in OB-1 (Fig. 5 and Table 1).

The Bisan-Seto Strait, situated between Harima-nada Bay and Mizushima-nada Bay (Fig. 1-2), is one of the shallowest straits in the Seto Inland Sea with water depths of less than $20 \mathrm{~m}$ in many areas. At the time of the accumulation of the US facies (ca. 8,000 cal yrs BP), sea level rose sufficiently for seawater to inundate the Bisan-Seto area (Masuda et al., 2000). As a consequence, Osaka and Harima-nada Bays are thought to have been connected with Mizushima-nada Bay through the Bisan-Seto Strait (event (3) in Fig. 8). The ostracode number of $A$. spinifera s.l. and Trachyleberis sp. increases at the base of biofacies DS (Fig. 7). As mentioned above, these ostracodes in biofacies DS are found only in those regions of contemporary Osaka Bay that are influenced by tidal currents from the Akashi Strait (Yasuhara et al., 1999a). They are dominant in present-day Hiuchi-nada Bay near the Kurushima Strait (Yamane, 1998). Therefore, we infer that the study sites were affected by tidal currents from the western Seto Inland Sea, at the time represented by the base of biofacies DS (ca. 8,000 cal yrs BP) (Fig. 8).

After the opening of the Bisan-Seto Strait, the tidal currents from the Akashi Strait intensified with time, as the Jomon transgression continued. Such phytal genera as Aurila, Cythere and Loxoconcha, and open sandy shoreface species such as Schizocythere spp., are common in biofacies DS. There is a rapid increase in ostracode number for $A$. spinifera $\mathrm{s}$. 1. and Trachyleberis sp. at sample number 11 in OB-1 (ca. 6,600 cal yrs $\mathrm{BP}$ ), which reaches a maximum at sample number 10 in $\mathrm{OB}^{-1}$ (ca. $5,470 \mathrm{cal}$ yrs $\mathrm{BP}$ ). The percentages of these species in assemblages also peak around the horizon represented by sample number 10 . The largest number of species occurs around sample number 9 (ca. 4,460 cal yrs BP) (Fig. 5 and Table 1). The influence of tidal currents from the Akashi Strait reached its maximum around sample number 10 in $\mathrm{OB}^{-1}$. The maximum flooding surface occurred around the time represented by sample number $10(\mathrm{C}$ in Fig. 8). Many specimens of sandy and phytal ostracodes, which lived in the intertidal zone and shorefaces around the Akashi Strait, were transported with sandy sediments to deeper muddy bottoms. In this way, a mixture of ostracode faunas gave rise to the maximum ostracode numbers and species numbers. The presence of such middle sublittoral species as C. $u c h i o i$ and a peak in the ostracode number of deep mud species in sample number 10 also support this conclusion. Masuda et al. (2000) suggested that a peak in sea level occurred at ca. 5,300-5,000 cal yrs BP in Osaka Bay. Therefore, the age and paleo-water depth of the maximum sea level estimated in our study, correspond well with the results from the depositional curve of $\mathrm{OB}^{-1}$ (B in Fig. 8), and to the sea-level curve on the Osaka Plain (A in Fig. 8). Vertical changes in the structure and composition of ostracode assemblages at $\mathrm{OB}^{-2}$ are similar to those at OB-1. For example, the number of open water species increases upwards and reaches its maximum at sample number 106 (Fig, 6).

The boundary between biofacies DS and DM (ca. 2,000-1,600 cal yrs BP in OB-1) is situated between the horizon of the last deposition of sand derived through the Akashi Strait (event (5) in Fig. 8) and the starting horizon of intense deposition of flood clay from the Yodo River at 
the eastern margin of Osaka Bay (event (6) in Fig. 8). Such sand-dwellers as A. spinifera s.l., Trachyleberis sp. and Schizocythere spp. decrease in this interval, suggesting a decrease in tidal currents from the Akashi Strait. Both "form A" and "form M" of B. bisanensis increase in biofacies DM. A decrease in species number from the upper biofacies DS to DM also suggests that depositional environments changed, becoming enclosed organic matter-rich bays with time.

The extent of tidal currents flowing from the Akashi Strait and that of the inflow of flood clay from the Yodo River have influenced the composition and structure of ostracode assemblages in Osaka Bay off Kobe.

\section{Brief comments on the distribu- tional pattern of Bicornucythere}

One of the representative species inhabiting Japanese enclosed muddy bays is $B$. bisanensis (Ikeya and Shiozaki, 1993). Ishizaki (1972) first recognized a size variation in Japanese $B$. bisanensis and assumed that the difference of valve size was due to the mode of reproduction. Abe and Choe (1988) and Abe (1988) distinguished four different forms ("forms A", "M", "P" and "G") within the eastern Asian B. bisanensis populations on the basis of carapace size and shape. Of these, "form A" and "form M" have been identified in Japan (Fig. 3). "Form A" has a larger and thicker carapace than "form $\mathrm{M}$ " in the corresponding juvenile and adult stages. "Form A" has been reported widely from Japanese enclosed bays. Its fossil record suggests it is the oldest of the four forms, extending into the Pliocene in western Japan (Abe, 1988). Only three reports have so far been published on the distribution of "form M" from Japan (Ishizaki, 1968 ; Iwasaki, 1992 ; Yasuhara et al., 1999a). Only "form M" is extant in Uranouchi Bay in southern Shikoku, which faces the Pacific Ocean (Ishizaki, 1968; Abe, 1988). Iwasaki (1992) found that "form M" predominates over "form A" in the shallower areas of contemporary Ariake Bay off Shirakawa, western Kyushu and in the lower- and uppermost samples from Holocene bore hole cores in the Kumamoto Plain near Ariake Bay. Conversely, Yasuhara et al. (1999a) reported that both forms are abundant in Osaka Bay at water depths of $8.8-37.2 \mathrm{~m}$. They did not recognize a trend comparable in distribution to that reported in Ariake Bay. "Form M" has so far been reported from enclosed bays in western Japan.

We investigated temporal changes in individual numbers of both "form A" and "form M" of $B$. bisanensis from a Holocene bore hole core at Kitatsumori in the Osaka Plain $\left(34^{\circ} 38^{\prime} 49^{\prime \prime} \mathrm{N}\right.$, $\left.135^{\circ} 29^{\prime} 09^{\prime \prime} \mathrm{E}\right)$ to correlate with those from off Kobe (Table 2). This core is the same as that used by Miyahara et al. (1999). Table 2 gives the age, in calendar years before the present,

Table 2 Sample horizon, radiocarbon age (calender yrs BP), sample weight (g) and individual number of "form A" and "form M" of Bicornucythere bisanensis from Kitatsumori

\begin{tabular}{|c|c|c|c|c||c|c|c|c|c|}
\hline horizon(m) & cal yrs BP & weight(g) & "form A" & "form M" & horizon(m) & cal yrs BP & weight(g) & "form A" & "form M" \\
\hline 8.50 & 1160 & 80.00 & & 1 & 14.50 & 3800 & 57.59 & 52 & 2 \\
9.00 & 1220 & 76.90 & & 4 & 14.95 & 5270 & 77.38 & 41 & \\
9.50 & 1300 & 80.00 & & 4 & 15.00 & 5390 & 80.00 & 32 & \\
10.00 & 1410 & 60.00 & 44 & 17 & 15.40 & 5630 & 75.44 & 29 & \\
10.50 & 1510 & 23.59 & 34 & 9 & 16.00 & 5930 & 40.00 & 42 & \\
11.00 & 1620 & 80.00 & 31 & & 16.50 & 6110 & 80.00 & 58 & \\
11.50 & 1730 & 40.00 & 37 & 1 & 17.00 & 7110 & 29.42 & 78 & 1 \\
11.70 & 1800 & 64.70 & 32 & & 17.50 & 7620 & 73.72 & 54 & \\
12.00 & 1900 & 73.00 & 20 & & 18.00 & 7860 & 80.00 & 1 & \\
12.35 & 1970 & 33.00 & 24 & 15 & 18.50 & 7980 & 77.23 & & 1 \\
12.50 & 2020 & 38.86 & 20 & 9 & 19.00 & 8130 & 60.00 & 68 & \\
13.00 & 2300 & 80.00 & 18 & & 19.50 & 8310 & 80.00 & & 2 \\
13.38 & 2600 & 20.00 & 23 & & 19.70 & 8390 & 80.00 & & 5 \\
14.00 & 3170 & 20.00 & 21 & 3 & \multicolumn{6}{|l}{} \\
\hline
\end{tabular}

Radiocarbon ages were estimated from depositional curve of Miyahara et al. (1999). 
of all ostracode-bearing samples from Kitatsumori as calculated on the basis of the depositional curve constructed by Miyahara et al. (1999). Specimens from samples in $\mathrm{OB}^{-1}$ older than ca. 8,350 cal yrs BP are all "form M" (Fig. 7). All specimens in biofacies BM and SM in OB-2 are also "form M" except for one juvenile from sample number 236 (Fig. 6). Furthermore, until ca. 8,310 cal yrs BP, only "form M" was present at Kitatsumori (Table 2). "Form A" first occurred in the period between 8,3108,130 cal yrs BP in Kitatsumori and between $8,350-8,020$ in $\mathrm{OB}^{-1}$ off Kobe, respectively. "Form A" subsequently dominated over "form M" in both Kitatsumori and off Kobe. After ca. $1,600-1,500$ cal yrs BP, the relative abundance of "form M" increased again. Only "form M" was present after 1,300 cal yrs BP in Kitatsumori. Yasuhara et al. (1999b) also reported similar temporal changes of both forms from a Holocene bore hole core in Sakai City in the Osaka Plain. According to these authors, "form A" was first occurred around 7,132 \pm 68 ${ }^{14} \mathrm{C}$ yrs BP. Whereas "form $\mathrm{M}$ " was present from around $1,079 \pm 68{ }^{14} \mathrm{C}$ yrs $\mathrm{BP}$ after which time it predominated over "form A". We have drawn certain conclusions on the migration of these forms of Bicornucythere in Osaka Bay on the basis of the above-mentioned observations. "Form M" first invaded Osaka Bay from the Kitan Strait, following the invasion of S. quadriaculeata during an early transgression, when the Akashi Strait was not yet established. The presence of one juvenile specimen of "form A" in the upper part of the LM facies in $\mathrm{OB}^{-2}$, however, suggests that "form A" was already living in Osaka Bay around the opening of the Akashi Strait. As the increase in relative sea level accelerated around ca. 8,000 cal yrs BP (Fig. 8), water depth increased rapidly in Osaka Bay. Therefore, "form A" invaded around Kobe and Kitatsumori. Inland areas were subsequently inundated with seawater. One of the reasons for the absence or scarcity of "form M" in Kitatsumori, Sakai City and off Kobe, during the time interval between ca. 8,000 and 1,600 cal yrs BP, may be that "form M" migrated to interior bays such as Kawachi Bay to the east of Kitatsumori. After ca. 2,000-1,600 cal yrs $\mathrm{BP}$, these interior bays disappeared and "form
M" returned to Kitatsumori and Kobe. Both forms occur widely in the present Osaka Bay in equal proportions (Yasuhara et al., 1999a).

\section{Conclusions}

1. An enclosed inner brackish bay existed off Kobe during the early Holocene transgression.

2. The Akashi Strait opened at ca. 9,700 cal yrs BP and inner to middle, enclosed shallow muddy bay species increased.

3. The number of individual of sanddwellers increased rapidly at ca. 8,000 cal yrs BP, when the Bisan-Seto Strait opened. Osaka, Harima-nada and Mizushima-nada Bays were interconnected and the Seto-Inland Sea has been formed.

4. "Form M" of B. bisanensis (Abe and Choe, 1988) was dominant in Osaka Bay off Kobe before the opening of the Bisan-Seto Strait. "Form A" subsequently invaded the region at ca. 8,350-8,000 cal yrs BP and outnumbered "form M" for several thousand years. "Form M" predominates over "form A" in the uppermost part of cores off Kobe and in the Osaka Plain.

5. The ostracode number, both of deep mudand sand-dwellers, reached its maximum at around 9.5-m core depth of $\mathrm{OB}^{-1}$, which accumulated at the time of maximum flooding (ca. 5,500 cal yrs BP).

6. Open marine sand-dwellers decreased after maximum flooding, suggesting a decrease in the influence of tidal currents through the Akashi Strait.

7. From ca. 1,600 to 1,100 cal yrs BP, organic matter-rich middle bay ostracodes again predominated throughout Osaka Bay off Kobe. This reflects a decrease in sandy sediment inflow from the Akashi Strait and an increased flood clay inflow from the Yodo River and other rivers.

\section{Acknowledgments}

We would like to thank Dr. Kunihiro Ishizaki of Ishinomaki Senshu University for critical reading of the manuscript. We also thank Dr. Yo Iwabuchi of Japan Coast Guard for his supply of core samples and Mr. Moriaki Yasuhara of Osaka City University for discussing ostracode assemblages from recent Osaka 
Bay. This study was supported by the Grantin-Aid for Encouragement of Young Scientist from the Japanese Ministry of Education, Science and Culture (No. 10740246).

\section{References}

Abe, K. (1988) Speciation completed? In Keijella bisanensis species group. Hanai, T., Ikeya, N. and Ishizaki, K. (eds.) Evolutionary biology of Ostracoda : Its fundamentals and applications: 919-925, Kodansha and Elsevier.

Abe, K. and Choe, K.-L. (1988) Variation of Pistocythereis and Keijella species in Gamagyang Bay, south coast of Korea. Hanai, T., Ikeya, N. and Ishizaki, K. (eds.) Evolutionary biology of Ostracoda : Its fundamentals and applications: 367-373, Kodansha and Elsevier.

Bodergat, A.M. and Ikeya, N. (1988) Distribution of Recent Ostracoda in Ise and Mikawa Bays, Pacific coast of Central Japan. Hanai, T., Ikeya, N. and Ishizaki, K. (eds.) Evolutionary biology of Ostracoda : Its fundamentals and applications : 413-428, Kodansha and Elsevier.

Frydl, P. (1982) Holocene ostracods in the southern Boso Peninsula. Hanai, T. (ed.) Studies on Japanese Ostracoda : 61-140, Bull. Univ. Mus., Univ. Tokyo, 20.

Fukusawa, H. (1995) Non-glacial varved lake sediment as a natural timekeeper and detection on environmental changes. The Quat. Res. (DaiyonkiKenkyu), 34, 135-149. (J+E)

Hanai, T., Ikeya, N., Ishizaki, K., Sekiguchi, Y. and Yajima, M. (1977) Checklist of Ostracoda from Japan and its adjacent seas. $119 \mathrm{p}$, Univ. Tokyo Press.

Horn, H.S. (1966) Measure of "overlap" in comparative ecological studies. Amer. Natur., 100, 419-424.

Ikeya, N. and Shiozaki, M. (1993) Characteristics of the inner bay ostracodes around the Japanese islands - The use of ostracodes to reconstruct paleoenvironments-. Mem. Geol. Soc. Japan, 39, 15 $-32 .(\mathrm{J}+\mathrm{E})$

Ikeya, N., Wada, H., Akutsu, H. and Takahashi, M. (1990) Origin and sedimentary history of Hamanako Bay, Pacific coast of central Japan. Mem. Geol. Soc. Japan, 36, 129-150. (J+E)

Irizuki, T., Fujiwara, O., Fuse, K. and Masuda, F. (1998) Paleoenvironmental changes during the last post glacial period on the western coast of the Miura Peninsula, Kanagawa Prefecture, Central Japan : Fossil ostracode fauna and event deposits in bore hole cores. Fossils (Palaeont. Soc. Japan), 64, 1-22. $(\mathrm{J}+\mathrm{E})$

Irizuki, T., Fujiwara, O. and Fuse, K. (1999) Taphonomy of fossil ostracode assemblages in Holocene deposits on the Miura Penninsula, central Japan. Mem. Geol. Soc. Japan, 54, 66-116. (J+E)

Ishizaki, K. (1968) Ostracodes from Uranouchi Bay,
Kochi Prefecture, Japan. Sci. Rept. Tohoku Univ., 2 nd Ser. (Geol.), 40, 1-45.

Ishizaki, K. (1972) Morphological variation in Leguminocythereis hodgii (Brady), Ostracoda (Crustacea) from Japan. Professor Jun-ichi Iwai Memorial Volume : 697-707.

Iwasaki, Y. (1992) Ostracod assemblages from the Holocene deposits of Kumamoto, Kyushu. Kumamoto Jour. Sci. (Geol.), 12, 1-12. (J+E)

Kajiyama, H. and Itihara, M. (1972) The developmental history of the Osaka Plain with references to the radio-carbon dates. Mem. Geol. Soc. Japan, 7, 101-112. $(\mathrm{J}+\mathrm{E})$

Kamiya, T. and Nakagawa, T. (1993) Ostracode fossil assemblages in the Holocene shell bed found in Takahama-Cho, Fukui Prefecture, Central Japan. Bull. Dept. Nat. His. Fukui City Mus., 1, 115-133. (J+ E)

Maeda, Y. (1976) The sea level changes of Osaka Bay from $12,000 \mathrm{BP}$ to $6,000 \mathrm{BP}$, environmental changes in the Osaka Bay area during the Holocene Part-I. Jour. Geosci., Osaka City Univ., 20, 43-58.

Maeda, Y. (1978) Holocene transgression in Osaka Bay, environmental changes in the Osaka Bay area during the Holocene Part-III. Jour. Geosci., Osaka City Univ., 21, 53-63.

Masuda, F., Miyahara, B., Hirotsu, A., Irizuki, T. Yoshikawa, S. and Iwabuchi, Y. (2000) Temporal variation of Holocene Osaka Bay condition estimated from a core in off-Kobe, Japan. Jour. Geol. Soc. Japan, 106, 482-488. (J+E)

Miyahara, B., Masuda, F., Irizuki, T., Fujiwara, O. and Yoshikawa, S. (1999) Holocene sea level curve and paleoenvironments reconstructed from a core in Osaka, Japan. Saito, Y., Ikehara, K. and Katayama, H. (eds.) Land-sea link in Asia: "Prof. Kenneth O. Emery Commemorative International Workshop": 415-420, Proceedings of an international workshop on sediment transport and storage in coastal seaocean system, STA (JISTEC) and Geol. Surv. Japan.

Onodera, K. and Ohshima, K. (1983) Geomorphological development in the eastern Seto Inland Sea. Bull. Geol. Surv. Japan, 34, 217-239. (J+E)

Ota, Y., Matsushima, Y., Miyoshi, M., Kashima, K., Maeda, Y. and Moriwaki, H. (1985) Holocene environmental changes in the Choshi Peninsula and its surroundings, easternmost Kanto, central Japan. The Quat. Res. (Daiyonki-Kenkyu), 24, 13-29. $(\mathrm{J}+\mathrm{E})$

Ota, Y., Umitsu, M. and Matsushima, Y.(1990) Recent Japanese research on relative sea level changes in the Holocene and related problems. The Quat. Res. (Daiyonki-Kenkyu), 29, 31-48. (J+E)

Schornikov, E. I. and Tsareva, O. A. (1995) New Ostracoda of the genus Aurila from the N.W. Pacific. Mitt. Hamb. Zool. Mus. Inst., 92, 237-253.

Yamane, K. (1998) Recent ostracode assemblages from Hiuchi-nada Bay, Seto Inland Sea of Japan. Bull. Dept. Nat. His. Ehime Pref. Sci. Mus., 3, 19-59. 
$(\mathrm{J}+\mathrm{E})$

Yasuhara, M., Yoshikawa, S. and Irizuki, T. (1999a) Recent Ostracoda from Osaka Bay, southwestern Japan. Proc. 9th Symp. Geo-environments and Geotechnics, 167-172. (J+E)

Yasuhara, M., Yoshikawa, S., Irizuki, T. and Nanayama, F. (1999b) Analyses of depositional environments of the Holocene Namba Formation, Central Japan, based on fossil ostracode fauna. Abstracts, the 106th Annual Meeting of the Geological Society of Japan, 43. (J)

Zhao, Q. and Wang, P. (1988) Modern Ostracoda in sediments of shelf seas off China : quantitative and qualitative distributions. Oceanologia et Limnologia Sinica, 19, 553-561. (C+E)

$(\mathrm{C}+\mathrm{E})$ in Chinese with English abstract, $(\mathrm{J})$ in Japanese, $(\mathrm{J}+\mathrm{E})$ in Japanese with English abstract

\title{
神戸沖ボーリングコアにおける完新世貝形虫群集の垂直変化 一西日本の海峡の開口と相対的海水準変動に関連して一
}

\author{
入月俊明 $* 1$ 増田富士雄 $* 2 \cdot$ 宮原伐折羅 $* 2$. 広津淳司 $* 3$. \\ 植田静喜 $* 3 \cdot$ 吉川周作 $* 3$
}

（要 旨）

神戸沖の大阪湾で掘削された 2 本のボーリングコア (OB-1 と OB-2)を用いて貝形虫化石を調查した. 56 試 料から 52 種の貝形虫類が同定された。 これらの貝形虫 化石群集は数量解析に基づき， 5 つの化石相に分けられ た。すすなわち，下位加ら化石相は BM(湾汽水泥底相)， $\mathrm{SM}$ (湾奥泥底相)，SS(湾奥砂質泥底相)，DS(湾中央砂 質泥底相), DM(湾中央泥底相)に变化する. 約 11,000 10,000 年以前は閉鎖的内湾奥(水深 $2 \sim 7 \mathrm{~m}$ ) に優占する 汽水性種が多産する。約 9,700 年前に明石海峡が開口 し, 湾奥加ら湾中央部の浅海泥底種が増加した。貝形虫 群集は大阪湾之播磨灘が水島灘之通じた約 8,000 年前に 変化しはじめた。明石海峡からの潮流か強くなるにつれ て，潮間帯や外浜の種が砂質堆積物ととあに多量に深い 神戸沖の大阪湾に運搬された。潮間帯から外浜に生息す
る種と湾中央部の深海泥底種の産出個体数が最大になる 時期は 5,500 年前前後である.このことは神戸沖が明石 海峡からの潮流の影響を強く受けるとと屯に, 古水深が 最大になったことを意味している(最大古水深は約 33 m). その後, $2,000 \sim 1,600$ 年前頃からの海退により, こ れらの外洋性の種は減少し, 閉鎖的で有機物の多い湾の 泥底に生息する種が増加しはじめた。これらの内湾性種 は, 明石海峡からの粗粒堆積物の運搬が減り, 淀川から の洪水性粘土の供給が増加することにより，さらに増加 した，本試料中には，日本の内湾に普遍的に生息する Bicornucythere bisanensis が含まれ，その中で $\mathrm{M}$ 型が 大阪湾の南の紀淡海峡から最初に侵入し, その後, 約 8,350 ～ 8,000 年前になって A 型が優占するようになっ た.

\footnotetext{
* 1 愛知教育大学教育学部理科教育講座地学領域 $\overline{\mathbf{T}} 448-8542$ 刚谷市井ヶ谷町広沢 1 . E-mail

*2 京都大学大学院理学研究科地質学鉱物学教室 $\mathbf{T} 606-8542$ 京都市左京区北白川追分町.

$* 3$ 大阪市立大学理学部地球学科 $\overline{\mathbf{T}} 558-8585$ 大阪市住吉区杉本 3-3-138.
} 